\title{
Application of Metaphor in Prison Break of Season One
}

\author{
SONG Gui-xia \\ Binzhou University, Binzhou, China
}

\begin{abstract}
In 2005, Prison Break of Season One witnessed the 18,000,000 audience rating in dull season in America for the unique artificial charm in America. One of the most important reasons of success lies in the frequent and sufficient use of metaphor which strengthens the artificial power tremendously. Metaphor is a very important technique of imagination, which reflects one concept to another concept and plays a very important role in the course of human's perception for the world. In the drama, tattoo, escaping group, paper crane, etc., all reflect the author's insight for the society, revolt, and protest, expressing his pursuit and yearning for freedom, love, and family.
\end{abstract}

Keywords: Prison Break, love and freedom, metaphor

\section{Metaphor Theory}

Conception metaphor theory is a new branch of cognitive linguistics study. It originates from the 1980s and this school's representatives are American productive linguist Claff and English philosopher Johnson. It states that humankind's cognition always bases on its own experience, our concept system, and thinking course by the construction of metaphors. Metaphor is not just a way of thinking and cognition which characterizes human being's thinking. As Claff (1980) dictates, metaphor is a very important technique of imagination, which reflects one concept to another concept and plays a very important role in the course of human's cognition of the world.

\section{Introduction to Prison Break}

Prison Break is a suspense, action, thriller, and crime serial drama written by Paul Scheuring, directed by Bob Lucy, Wentworth Miller and Dominic Purcell acted the leading roles. In August 2005, Fox TV Internet introduced the movie and created 18,000,000 audience rating in dull season. In 2006, it was broadcast and praised heatedly and enthusiastically, and honored the most classic American movie. The theme of Season One is to escape from the prison. The hero Michael devised to rob the bank and was caught and sentenced to put into Fox State Prison in order to rescue Lincoln Burrows who was trapped and sentenced to death and would be executed very soon. One of the most important reasons of success is that metaphors were appropriated widely and appropriation strengthens the artificial power tremendously besides the shape of different vivid typical characters. The use of metaphor of tattoo, escaping group, paper crane, weapon, and tools made expressiveness of the drama much more powerful.

\section{Tattoo-Symbol of Wisdom}

As a marvelous structuralist, Michael took advantage of expertise to make the whole structure picture of Fox prison into a body tattoo, inspired by the tattoo of a mailwoman. It took the tattoo expert two months to 
make Michael into a blueprint, while it should take an ordinary technician a couple of years to finish it. According to this body blueprint, Michael proceeded his whole escaping plan step by step. The tattoo runs through the plot of the movie in Season One as a clue which symbolizes Michael's wisdom for freedom and love.

Two episodes on the blueprint are devised creatively. One is that Michael suffered lunatic Haywire as his cellmate, who stayed awake all night only to concern for Michael's tattoo. Even he found Michael's secret and almost threatened him. Finally, Michael inflicted injury upon himself to drive away Haywire to the mental block.

The second episode is that the blueprint was damaged from skin burn for course searching. Michael lost part of the blueprint to the mental block and consequently was put into guardhouse for not confessing the reason for skin burn. In the guardhouse, Michael attempted to remember what about the part of blueprint he lost. He tore his clothes into pieces and patch up; however, he could not succeed and slam the wall desperately, ending up being oafish. Successfully, he was put into the guardhouse, which happened naturally or devised deliberately, vividly, and shockingly. In order to make up for the incomplete blueprint, Michael found out Haywire and woke up his memory on the blueprint. Unfortunately, he had to take him to escape. The sufferance of the blueprint symbolizes Michael's extraordinary wisdom and perseverance in the course of pursuit for love and freedom.

\section{Escaping Group-Symbol of Society}

Led by Michael, escaping group was made of three kind men, two evil persons and one lunatic. Michael represents the justice planning the whole program to escape and protest against the dark power. Nevertheless, he himself could not realize the escaping plan and he had to organize his team to carry it out.

The first choice of escaping team is his cellmate Fernando Sucre, who was trapped into prison for he robbed store for his girlfriend. In the first place, Fernando did not want to escape only to stay full-time prison and step out to meet his loving girlfriend. Finally, he worried about his girlfriend to marry other and joined the escaping team definitely. Fernando is Michael's best partner who stands for part of the power of justice.

Benjamin Miles "C-Note" Franklin has a strong sense of justice who was repatriated because he disgusted his officer to maltreat captive. Later, he had to do illegal transportation business for living and was put into jail. At the beginning, Michael did not want to involve more people into the escape; however, Benjamin found the secret of prison industry. Michael had to accept him.

Westmoreland is another important choice person although he did not step out of the prison in the end. Michael knew he had got a great amount of money who could afford what they needed for escaping. Westmoreland was a very kind-hearted person who had no more wrong record at all for 32 years since he had been in prison. In prison, Marilyn cat was his only sustenance. He refused Michael's suggestion and attraction to escape firmly. But later when he found that Berwick unexpectedly killed Marilyn since he could not tell him who was the killer of Bob, he turned out different to be a trouble-maker, making fire and shifting the blame on Berwick until he joined the escaping camp for his sick daughter. Westmorland's participation in escaping group exposed the evil reality where there was no accommodation for a good man.

Michael's choice person also includes John Abruzzi, who was very cruel and bloody and the main character of gangland. He could be the candidate because he was able to provide the indispensable traffic vehicle. 
Among the choices, T-Bag was the last one that Michael would like to take. T-Bag was an extremely gory killer, child abuse, and metamorphosis. He killed six girl students and then was put into prison. After that he forced his cellmate Seth to death and killed cell guard Bob cruelly. For T-Bag found the hole of escaping Michael had to accept him in.

David "Tweener" was also Michael's reluctant choice, since he really helped Michael to return his gold watch. However, Michael knew him very well that he ever sold friend and found their secret.

Haywire was also the have-to choice who knew the group's secret though Michael only wanted to get back the damaged part of the blueprint.

In order to fulfill his escaping plan, Michael was forced to take several members he did not really want to take. The group involves the justice and kindness-Michael and Lincoln Burrows, the love and freedom-Fernando Sucre, Benjamin Miles, the evil and cruelty-Theodore, John Abruzzi, theft and madness - Tweener and Haywire which symbolizes a real society. When the power of justice and kindness could not win temporarily by themselves, they should be combined with other forces and efforts to reach their goal. Actually, at any critical time, justice separates from evil abruptly and distinctively. Justice and kindness always take action and fulfill their duties in a good way whereas the evil and sin reach their goal in any tricks, even hurt and kill somebody else. T-bag killed Bob only to hide the escaping secret and be able to join the group. Berwick killed Westmorland's cat because he did not tell him who killed Bob. Although Michael and Lincoln were put in the same jail with other prisoners, they are absolutely different from other real prisoners.

During the lockdown, since Michael closed the air conditioner for cooling and made it warming for breaking the wall causing a disturbance, all the cellmates turned to be vehement and agitated. Berwick infuriated T-bag by humiliating his personal affairs and brought about a riot. All the cellmates showed their real nature to beat, smash and loot like robbers. The cell cops became the victims of the brutality and humiliation. Prisoners were all wild animals in nature, releasing the cumulating hatred and anger in their hearts.

However, Lincoln as a condemned prisoner managed to protect the innocent cell cop Bob who was beaten by T-bag hoodlum. Even a group of mobster intended to encroach on Sara. Fortunately, Michael hurried to save Sara successfully in time.

The escaping group implies that the real society is a mixture of good power and evil power. Good and evil are always companies who depend on each other and there always exits the constant fight between them. Sometimes the evil could get the upper wind. Only stick to strife could we obscure safety, love, and freedom.

\section{Paper Crane-Symbol of Love and Family}

Paper crane appeared in the drama repeatedly which symbolizes the pursuit and desire for family and kinship of Michael. The first time paper crane showed up in the desk which companied and encouraged him was also placed on Michael's missing of his brother. Once Michael visited Lincoln and mentioned the paper crane, whenever he woke up and found the paper crane in bed he knew that Lincoln came full of sweetness and warmth.

The following paper crane showed up on the grass. Michael left the paper crane to show himself to request to join the prison industry. It demonstrated Michael's power and courage in front of John Abruzzi, the character gangland.

Also paper crane symbolizes direction to freedom. Michael put the paper crane into the sewer of the infirmary to test the water road. Paper crane swimming smoothly indicated that the passage was unblocked. 
Until Michael thought to be transferred, he put the paper crane in Fernando's bed by which he passed on his trust. Also Michael expressed his firm decision and absolution for freedom.

Unexpectedly, the wardern Pope cast about to keep Michael in Fox prison. Hence paper crane showed up again in infirmary and directed the route of escaping.

In Western countries, most of people worship some kind of religion; whereas Michael was a non-believer who did not believe in any god, any government, or official that could save his brother and pardon his so called guilt. Only by depending on himself, his power, and wisdom, could he make it to rescue his brother. Paper crane represented his power and wisdom to freedom and love. Simultaneously, it implied the way to save officially could not succeed. Although she finally found the "killed" Steadman by Lincoln, the only ending was to die.

\section{Tool and Lethal Weapon-Wisdom and Cruelty}

As proverb goes, "although you are not able to swim, you part the waters thousands of miles by boat". Michael was good at applying different kinds of tools. The first artifact for escape was screw on the bench of the grass. Though as soon as he obtained it, the tricky T-bag found it and scratched it. And again Michael strived for it pretending to join them. Once Michael got tool at his hand, he employed the screw to lay down lavabo to dig hole for escape. Screw was the first key to freedom and love which showed Michael's wisdom.

The second artifact for escape was eggbeater. According to Hooke's law, the force is proportional to the extension. As Michael was a marvelous structuralist, he took advantage of his major knowledge lining out several stress point on the wall and broke each point using the eggbeater until he broke through the whole wall. Eggbeater revealed Michael's wisdom and knowledge again.

The third artifact was razor blade. Michael dug out the drug which he buried in his arm using the razor blade to delay Lincoln's execution time. Razor blade displayed Michael's super endurance and courage to resist against obstacle and difficulties.

Razor could be used by the justice while it could be used by the evil. T-bag plunged a razor blade into John's neck while pretending to wail bitterly in his chest, instantly John collapsed in the blood trembling. Razor blade evolved the massacre between the evil, even much brutal than the justice over the evil. The combat between T-bag and John later developed into an axe story. In the course of escaping, T-bag shackled himself with Michael avoiding being cast off by the group. This irritated John to cut down T-bag's arm off Michael. Everybody in the group felt so horrifying. Only John praised his good cutting skill. The razor plunging and axe wielding doomed T-bag's all-life imprison and John's death because of their inhumanness.

Razor also showed up in the third plot. Tweener could not bear gay cellmate's victimizing and violence and cut his lower part of his body using razor blade after requesting earnestly several times. In this plot, razor blade became the tool for protection. Being with monsters, you had to take your tool for yourself, otherwise you would be overwhelmed to die like Seth's suicide.

\section{Taj Mahal—Symbol of Love and Wisdom}

Taj Mahal more often meaning Crown of the Palace is an ivory-white marble mausoleum on the south bank of the Yamuna River in the Indian City of Agra. It was commissioned in 1632 by the Mughal emperor, Shah Jahan, to house the tomb of his favorite wife, Mumtaz Mahal. Taj Mahal is the witness of everlasting love. The warden Pope built a Taj Mahal to express his gratitude for his wife 39 years' support and loyalty without any complaint before their 40th anniversary celebration. In the end, it grew the counter for escaping which 
provided more time to escape as a good excuse until the last moment Michael kidnapped the warder to gain the time. Taj Mahal as one of the keys to escape runs through the whole drama and symbolizes the love and wisdom. Meanwhile for the warden Taj Mahal was only a daydream hard to achieve in that society full of evil.

\section{Names-Symbol of Characteristics}

In the drama, there are some names which reflect distinctive characteristics. For example, Kellerman was a real killer who was employed by the vice-president. Kellerman killed bishop for shutting up his mouth and killed L.J.'s mother and step father to impute L.J.. And he tempted to explode Veronica to stop her to investigate the case. Later, he deserted his coworker in the trap to death for preserving his own position in vice-president's eyes. Even he killed his old partner Danny. The image of killer reflected cruelty and violence in order to satisfy their own interests.

The second name is vice-president Caroline's brother Steadman indicated a dead man. In order to realize his personal political conspiracy Caroline plotted her blood brother as a "dead" man killed by Lincoln. Steadman was a dead man in the whole drama. For his sister's political conspiracy, he was imprisoned in an apartment and was excised his teeth. He lived out of human environment and lost his identity like a dead man.

The third name is Haywire meaning out of control which described himself exactly. Haywire is a lunatic. He was put into prison for killing his own parents. He was a tragedy without love and family only was forced to take calmative in low downturn. As the doctor diagnosed Haywire with Michael all suffered the same potential depression, either they could be genius like Michael with high intelligent quotient or would catch chronic dementia like Haywire with low IQ.

Verolinca represented the positive character of the government whose name meant image of Jesus. Another attorney's name Nike also meant goddess of success. The warden's name Pope meant Roman bishop. These three names were all related closely with religion but they were either shot dead or kidnapped by rebels. This implied that only rising up to resist the government instead of depending on religion could the dream of love and freedom be realized. The usage of symbol could highlight the typical characteristic and strengthen the expression.

\section{Conclusion}

The drama employs the writing technique of metaphor to mark the vivid characters and the theme. This technique increases the power of expression and art attraction which moves the audience greatly.

\section{References}

Dutemple, L. A. (2003). The Taj Mahal. Chicago: Learner Publications Company.

JIN, L. S. (2011). The most classic movie —Prison Break. Retrieved from https://movie.douban.com/review/5129429/

Lakoff, G., \& Johnson, M. (1980). Metaphors we live by. Chicago: University of Chicago Press.

Pickover, C. (2007). Archimedes to Hawking: Laws of science and the great minds behind them. Retrieved from https://books.google.com/books?id=SQXcpvjcJBUC\&pg=PA74\&dq=hooke\%27s+law\&hl=en\&sa=X\&ved=0ahUKEwjgq4

WwpOLQAhWp44MKHSTBDpwQ6AEIMjAD\#v=onepage\&q=hooke's\%20law\&f=false

Spengler, O. (1991). The decline of the west. Oxford: Oxford University Press.

Strauss, L. (1953). Natural right and history. Chicago: University of Chicago Press. 